\title{
Hypocalcemia-Induced Convulsion: A Rare Case in Emergency Department
}

\author{
Oguzhan Ozcan ${ }^{1}$, Ali Karakus ${ }^{2}$ \\ ${ }^{1}$ Mustafa Kemal University Faculty of Medicine Medical Biochemistry - Hatay/Turkey \\ ${ }^{2}$ Mustafa Kemal University Faculty of Medicine Emergency Department- Hatay/Turkey
}

*Corresponding Author: Ali Karakus, Mustafa Kemal University Faculty of Medicine Emergency Department-Hatay/Turkey

Keywords: Hypocalcemia, convulsion, impaired consciousness

\section{DEAR EDITOR,}

Impaired consciousness and convulsion may be resulted from metabolic $(85 \%)$ and central nervous system disorders caused by trauma, infections and fluid-electrolyte imbalance, besides epilepsy. In this study we aimed to present a case of hypocalcemia which is a rare cause of convulsion.

An 80-year-old male admitted to emergency room with sudden onset of impaired consciousness and convulsions. Medical history revealed that the patient had dysarthria and ataxia due to previous cerebellar ischemic attack and also had hypertension and chronic renal failure. Clinical examination revealed a confused patient who has a moderate clinical condition and Glasgow Coma Scale score of 12 , blood pressure was $130 / 80 \mathrm{mmHg}$, respiratory rate was 40 breaths per minute, heart rate was 80 beats per minute and sinus tachycardia rhythm was observed in the electrocardiography (ECG) examination in admission.

Initial laboratory investigation results included a lower serum total calcium level of $6,8 \mathrm{mg} / \mathrm{dL}$ (8.5$10.2 \mathrm{mg} / \mathrm{dl}$ ), ionized calcium level of $0.85 \mathrm{mmol} / \mathrm{L}(1.12-1.32 \mathrm{mmol} / \mathrm{L})$ and higher $\mathrm{BUN}$ and creatinine (respectively, $75 \mathrm{mg} / \mathrm{dL}$ and $2.8 \mathrm{mg} / \mathrm{dL}$ ); glucose, $110 \mathrm{mg} / \mathrm{dL}$; alb, $4.2 \mathrm{~g} / \mathrm{dL} ; \mathrm{pH}, 7.4$; $\mathrm{HCO}_{3}, 23.5 \mathrm{mEq} / \mathrm{L} ; \mathrm{PCO}_{2}, 40.4 \mathrm{mmHg}$ and $\mathrm{PO}_{2}, 98.6 \mathrm{mmHg}$. Hematological results were within normal limits. No significant new abnormalities were seen in cranial computerized tomography (CT).

Intravenous calcium therapy (2 flacon within $100 \mathrm{cc}$ dextrose, 5\%) were started immediately and monitorized in emergency department.

After invention, control serum ionized calcium values were $1,2 \mathrm{mmol} / \mathrm{L}$, within normal limits. Patient was considered to be hypocalcemia-induced seizure seconder to chronic renal failure. The patient was discharged with oral $1 \mathrm{~g} /$ day calcium treatment.

Hypocalcemia is one of the important electrolyte disorders and can lead to increasing excitability in the central nervous system Hypocalcemia plays an important role in many neurological manifestations including convulsion, delirium and tetany and have been documented by previous clinical observations. It can be presented with convulsion, syncope and tetany. It takes into consideration for differential diagnosis in patients presented with convulsion and impaired consciousness in emergency department.

\section{REFERENCE}

[1] Bahceci M, Arıkan S. Hypocalcemia in Endocrine Agents and Acute Hypocalcaemic Crisis Treatment. Turkiye Klinikleri J Surg Med Sci 2006;2(7):50-6

Citation: O. Ozcan \& Ali Karakus, "Hypocalcemia-Induced Convulsion: A Rare Case in Emergency Department", International Journal of Clinical Chemistry and Laboratory Medicine (IJCCLM), vol. 3, no. 3, p. 16, 2017. http://dx.doi.org/10.20431/2455-7153.0303003

Copyright: (C) 2017 Authors. This is an open-access article distributed under the terms of the Creative Commons Attribution License, which permits unrestricted use, distribution, and reproduction in any medium, provided the original author and source are credited. 